\title{
Analysis Marketing Strategy of Coffee Luwak Cikole; A Case Study
}

\author{
Satim Hamid, Pupung Purnamasari \\ STIE PERTIWI \\ shamco_prima@yahoo.co.id
}

\begin{abstract}
This research is the result of a survey in the coffee Luwak Cikole Lembang Bandung production house that produces Luwak coffee from beans which are first eaten by mongoose animals. the purpose of this research is to deeply understand the process of implementing marketing and developing marketing strategies. The research method used is qualitative with field survey techniques. the results of the research show about the marketing process of Cikole Luwak coffee through several marketing processes including through product variables, price, promotion and distribution. The marketing process is carried out mostly through word of mouth and publications through social media sites such as WhatsApp, Facebook and other social media. problem analysis developed from observations using a SWOT analysis faced by $\mathrm{CV}$. Kopi Luwak Cikole as a local business actor in the coffee industry

Keywords- Luwak Coffee, Marketing strategy, SWOT Analysis, Fermentation process, Social media
\end{abstract}

\section{INTRODUCTION}

Coffee is a well-known beverage throughout the world and the tradition of drinking coffee continues to grow. This can be seen from the many countries that cultivate coffee as a superior commodity. Indonesia is currently ranked fourth as the largest coffee producing country in the world with a production level of 648,000 tons / year. its position under Colombia, Vietnam and Brazil.

There are two types of coffee, namely Arabica and Robusta types. Besides developing these two types of coffee, several Indonesian entrepreneurs such as CV. Kopi Luwak Cikole develops other types of coffee, Luwak coffee. This coffee comes from defecating mongoose animals. civet weasel is a mammal (Paradoxurus hermaphrodites), this animal has various names, among others, musang (common name, Betawi), Careuh bulan (Sunda), luak atau luwak (Jawa), and common palm civet, common musang, house musang or toddy cat. This type of coffee is a typical original coffee from Indonesia and is produced in limited quantities. the scarcity and difficulty of collecting Luwak coffee beans and their distinctive aroma have caused the price of civet coffee to be very high. During this time luwak coffee is consumed in the country and to meet consumer demand abroad.

The high demand for coffee has increased the number of luwak coffee business operators. along with the increasing demand for luwak coffee, the need for raw materials also increases. This has encouraged the development of the Luwak coffee business by breeding and planting coffee trees. During this time there are two ways in producing Luwak coffee, namely by finding coffee beans that are eaten by mongoose animals and excreted through defecation, then the defecations are collected or cleaned to be processed into coffee. the second way is by raising luwak animals, because getting seeds from wild luwak is very difficult. the amount of coffee produced by fermentation depends on the number of luwak that are kept.

However, luwak coffee has a special characteristic, namely the natural fermentation process can distinguish flavors / aromas with other coffees. in addition, the fermentation process is a selling point for Luwak coffee. In Indonesia, there are many who have developed and cultivated Luwak coffee, including in Aceh, Lampung, West Java and Bali. Luwak coffee cultivation is generally carried out in highland areas because it is adapted to the animal's habitat.

\section{LITERATURE REVIEW}

\subsection{Marketing}

Marketing is not "getting people to buy from you" , "eliciting a sale" or (as an eloquent acquaintance once put it). Marketing is not just "selling" "advertising" or "all the promotional activities used to do business". Marketing is not a synonym for "Promotion"(Cowan, 2014:19); "Marketing" is the craft of utilizing the resources at your disposal to best meet the needs of the end user as well as a desired outcome for the owners of the organization(Cowan, 2014: 19); Marketing, a simplistic concept is introduced, which is called "the 4P's of Marketing" (Cowan, 2014: 23); Marketing consists of actions undertaken to elicit desired 
responses from a target audience (Kotler, 2000:7); As a discipline, marketing is in the process of transition from an art which is practiced to a profession with strong theoretical foundations (Baker,2003:3); Marketing is both a managerial orientation-some would claim a business philosophy- and a business function (Baker,2003:4); Marketing therefore is all about mutually satisfying exchange relationships for which the catalyst is the producer's attempt to define and satisfy the consumer's need better (Baker,2003:8); The marketing concept holds that the key to achieving organizational goals consists of the company being more effective than its competitors in creating, delivering, and communicating customer value to its chosen target markets. The marketing concept rests on four pillars: target market, customer needs, integrated marketing, and profitability (Kotler, 2000:12); Marketers use numerous tools to elicit the desired responses from their target markets. These tools constitute a marketing mix. Marketing mix is the set of marketing tools that the firm uses to pursue its marketing objectives in the target market (Kotler, 2000:9)

Kotler dan Keller (2012:13) defined marketing is a social process by which individuals and groups obtain what they need and want through creating, offering and want freely exchanging product and services of value with others. While Stanton (2004:7) states marketing is a total system of business activities designed to plan, price, promote and distribute want satisfying product to target markets to achieve organizational objectives". Keagan (2002:425) defined marketing is the process of focusing the resources and objectives of an organization an environmental opportunities needs. Marketing has been defined in a somewhat basic way as whatever comes between production and consumption, the distribution of products and services to those who buy them (Foxall,2003:120). In marketing, the competitive space is generally characterized in terms of market segmentation (Wesley, 2003:66). More recently, marketing has recognized much more explicitly this further range of issues, including the key role of competition and the importance of a longer term so-called relationship perspective, particularly in the context of customers [1]; Marketing activity has become crucial for enterprises because successful marketing enables companies to gain and retain customers, so they allocate significant resources to this area (Aydin and Mtetwa, 2016: 533).

\subsection{Marketing Strategy}

Marketing strategies, the means by which the objectives will be achieved, are generally concerned with the 'four Ps' (Malcom, 2003: 94). Marketing strategy sometimes claims to provide an answer to one of the most difficult questions in our understanding of competitive markets. Marketing strategy, as with the field of strategy itself, has had to address the continual dialectic between analysis and Action or in more common managerial terms between strategy formulation and strategic implementation (Wesley, 2003:53); Marketers use numerous tools to elicit the desired responses from their target markets. These tools constitute a marketing mix. Marketing mix is the set of marketing tools that the firm uses to pursue its marketing objectives in the target market (Kotler, 2000:9). Marketing-mix decisions must be made to influence the trade channels as well as the final consumers. However, it can develop new products and modify its distribution channels only in the long run (Kotler, 2000:9)

According to (Assauri,2017: 168) marketing strategy is a comprehensive, integrated, and unified plan that provides guidance on the activities that will be carried out in order to achieve the marketing objectives of a company. In other words a marketing strategy is a set of goals and objectives, policies and rules that give direction to the company's marketing efforts from time to time, at each level and reference and allocation, especially in response to the company in the face of the environment and conditions of competition that is always change. Kotler and Keller (2009: 204). explained that the marketing strategy is a decision making about marketing costs, marketing mix, marketing allocation with the expected environmental conditions and the conditions of competition faced. Cravens (2000) states that marketing strategies must have important implications, namely interactions between consumers and companies, being able to identify company goals as well as customer satisfaction and needs. According to McCarthy the aim of the company's marketing strategy is that the strategy implemented is more effective and achieves sustainable profitability, so it must be oriented to Product, Price, Promotion and Place (Kotler and Armstrong, 2008: 58). According to (Swastha.2005) marketing strategies consist of three types of decisions, namely target consumers, consumer 
desires, and marketing mix. These three elements determine the direction of the company's marketing strategy. The strategy is a long-term plan that is used as a guide for company activities. In addition, the strategy consists of various elements focused on the marketing elements. A successful marketing strategy is generally determined by one or several marketing mix variables. And (Tjiptono,2006: 30) states that the marketing mix is a tool used by marketers to shape the characteristics of the products and services offered and these tools are used as strategy development, both short and long term. so companies can develop product strategies, prices, distribution or promotion [2].

\subsection{Marketing Mix}

Marketing mix management paradigm has dominated marketing since 1940s and McCarthy (1964) further developed this idea and refined the principle to what is generally known today as 4Ps (Jain,2013,26); Marketing cannot be separated from the 4 components of marketing (4P), namely product, price, promotion and place. The marketing strategy that has been introduced by Jerome McCarthy in 1960 is still used until the present day (Er and Simon, 2015:2). 4Ps delimits four distinct, well-defined and independent management processes (Jain,2013,25); Popovic (2006) The concept of 4Ps has been criticized as being a production-oriented definition of marketing, and not a customer-oriented (Jain,2013,26); Gronroos,1994) states the main reasons the marketing mix is a powerful concept are. It makes marketing seem easy to handle, allows the separation of marketing from other activities of the firm and the delegation of marketing tasks to specialists; and-the components of the marketing mix can change a firm's competitive position (Jain,2013:23 ) (Mostaani,2005) By using marketing mix, cooperatives can further meet their members' needs and expand their sale in their nonmember markets (Jain 2013:24). Marketing mix according to Stanton (2004: 24) has two variables, namely variables that can be controlled such as product, price, promotion and place. The second variable is uncontrollable such as the economic, political, technological and cultural environment. Kotler and Keller (2012: 379) defined marketing mix is the set of marketing tools that the firm uses to pursue its marketing objectives in the target market.

\subsubsection{Product}

Effective marketers accomplish this by promoting and delivering high-quality products and services at fair prices to the other parties over time (Kotler, 2000:7); Quality good products, and product configuration are major determinants of the customer purchase decision (Sam et al, 2016:7); Davis (1997) states that product is all necessary components and elements to do a service which generate value for customer (Jain, 2013 ); The Product in service marketing mix is intangible in nature. A product is anything that can be offered to a market for attention, acquisition, use or consumption that might satisfy a want or need (Kotler,2002) (Sarkar et al, 2012:274); Stanton (1993:192) states that a product is a set of tangible and intangible attributes, including, packaging, color, price, manufactures prestige, and manufactures and retailer, which the buyer may accept as offering want-satisfaction. Products and services are often technologically complex and this, combined with bulk purchasing, leads to many industrial purchases being of high value (Turnbull and Leek, 2003:147); Weigand (1968) defines a product as 'a variety of promises to perform'. (Turnbull and Leek, 2003148). In general, products have three basic levels, namely: 1 . Core products, namely the basic and important benefits that consumers want to buy; 2 . Tangible product, i.e. attributes attached to products such as brand, color, model and packaging; and 3. Augmented product, namely additional services such as product marketing, additional product completeness, and warranty

\subsubsection{Price}

Pricing policy is the course of action or guiding philosophy that helps a business firm to make pricing decisions smoothly and perfectly (Sarkar et al, 2012: 274); According to Kotler (1995: 120) that price is the only element in the marketing mix that produces sediment. Whereas Stanton (1993: 308) defines price as the value mentioned in rupiah or other monetary media. Regarding the reason the company determines the price goal is to maintain the viability of the company, maximize company profits in the short run, maximize revenue for the short term, encourage maximum sales growth, filter and select the maximum market, and has an advantage in the quality of its products.

\subsubsection{Promotion}

Promotion have become a critical factor in the service marketing mix ( Sarkar et al, 2012:275); Promotions are important as they can inform consumers of product availability, generate public awareness of marketing activities and increase customer loyalty (Sam et al, 2016:4);Promotion is an important factor that should be taken into account in determining the success of an organization in order to achieve the desired goals (Er and Simon,2015:3); According to Kotler (2007) marketing communication 
mix (Promotion mix) consists of the specific blend of advertising, personal selling, sales promotion, public relations and direct marketing tools that the company uses to pursue its advertising and marketing objective (Sarkar et al, 2012:275)

According to William Shoel in Buchari Alma (2007: 179) that promotion is marketers' effort to communicate with the target audience. Communication in the process of influencing others' behavior by sharing ideas, information or feeling with them. Promotion activities are carried out with mediums of advertising, personal selling, sales promotion, and publicity.

\subsubsection{Place}

According to Larry Steven (2009) that the place or distribution channel is the operator's activity to ensure that the product is always available in the market by using the services of middlemen, retail and wholesale services, and strategic location to market the services and product (Er and Simon,2015:3); Place in case of services determine where is the service product going to be located (Sarkar et al , 2012: 274);According to Larry Steven (2009) that the place or distribution channel is the operator's activity to ensure that the product is always available in the market by using the services of middlemen, retail and wholesale services, and strategic location to market the services and product (Er and Simon,2015:3); Place in case of services determine where is the service product going to be located (Sarkar et al , 2012: 274); According to the American Marketing Association cited by (Swastha,2008: 285) distribution is an organizational unit structure within companies and outside companies that consists of agents, dealers, wholesalers, and retailers through a commodity, product or service marketed. In choosing a distribution channel there are several things that must be considered by the company, namely: 1. Market characteristics and location of purchase; 2 . The channeling institutions involved; 3. Handling inventory, managing inventory at the most economical level; 4. Transportation equipment used.

\section{RESEARCH METHODS}

This research use Descriptive qualitative approach. Descriptive qualitative according to (Sugiyono,2003: 40) is a study that aims to obtain descriptive characteristics of research variables, namely the internal environment in the company which consists of human resources, finance, factors of production, and research and development. While the characteristics of external factors such as economic conditions, politics, technology, government policies, competitors, consumer suppliers and culture.

The research method used is descriptive survey, which is to see a general description of the variables or relationships between variables only. In addition, researchers also use descriptive analysis method, which is a method that interprets data obtained with facts that are seen at the time of research so that a clear picture of the object under study can be obtained. Investigations conducted in a descriptive nature do not lead to testing the effect of the relationship between variables. The data obtained in the study consisted of data primers derived from direct sources through observation, interviews or questionnaires. Secondary data obtained from internet articles and libraries. Data collection techniques using various methods. According to Creswell (2017: 254) there are several ways to collect data, namely: a questionnaire by giving questions, both closed and open to respondents; 2 . Interview, namely collecting data by conducting direct interviews or question and answer with respondents in order to obtain additional data and confirm existing data; 3 Observation, namely observing activities to look at phenomena and looking for data by conducting direct observations. The aim is to collect data to be selected and adapted to the research object; 4 Documentation, namely the collection and recording of data from books, pictures and documents.

\section{SWOT analysis}

SWOT can provide an overview in implementing effective strategies based on environmental conditions. SWOT is an abbreviation of: Strengths. Excellence Resources (human resources, finance, factors of production, superior management techniques) owned by the company to be able to compete with competitors. This power can be controlled by the company; Weakness This weakness is inversely proportional to strengths, where companies experience a lack of resources, generally weaknesses can interfere with company performance and the vulnerable points that must be overcome by the company; Opportunities. Opportunities are external environments that support the development of a company even though its nature cannot be controlled, such as economic, political, cultural and technological circumstances. Threats. An external environment that is not profitable for the company can even threaten the sustainability of the company such as economic turmoil, politics, strong competitors and technology developed by competitors.

From the SWOT matrix, there will be four possible strategies that can be analyzed, namely: 1. SO Strategy. 
This position is utilized by the company in using internal strength to seize opportunities that exist outside the company; 2. WO Strategy. This position is carried out by the company by maximizing existing internal capabilities to minimize the company's weaknesses; 3. ST Strategy. This position is used by the company to maximize internal strength to avoid threats that exist outside the company; 4. WT Strategy. This position is applied by the company when the company faces pressures in order to get out of the problem, namely by minimizing weaknesses and avoiding threats

According to Porter in Purnomo (2007: 75) regarding the SWOT analysis above, even though the company has many strengths and weaknesses in dealing with competitors there are very important things, which have low cost competitive advantages, product differentiation and focus. This is called a generic strategy.

\section{RESULT AND DISCUSSION}

CV Kopi Luwak Cikole was established in January 2012, located in Kampung Babakan Cikole Village, West Bandung Regency. The company Kopi Luwak Cikole has a Luwak coffee product business with the brand Kopi Luwak Cikole. At present the company CV. Cikole Luwak Coffee has 200 tails of Luwak. The average price of coffee products is $\mathrm{Rp} 3,000,000$ to $\mathrm{Rp} 8,000,000 / \mathrm{kg}$. Luwak coffee prices are very high due to the availability of goods that are not balanced with consumer demand. During this time many requests come from Malaysia, Singapore, China, Korea, the Netherlands, Italy, Germany and other European countries.

Besides providing coffee products, coffee shops are also provided by showing the processing process so that visitors can get a more complete explanation. Besides developing promotions for Luwak coffee lovers, the manager also developed educational tours for school children to introduce the Luwak coffee production process and how to care for the animals. Most coffee shop visitors get information from their friends and get from other media, such as the internet and social media such as Facebook, Twitter, and WhatsApp.

Most of the CV production. Kopi Luwak Cikole for the export market with a make to order system, which is to order. The amount of production is adjusted by the number of orders. However, for products for Cikole Kopi Luwak Cafe, the production process is done in a make to stock manner. Products are made based on the number of visitors who come to the cafe.
So that many visitors from abroad and domestic who come directly to enjoy Luwak coffee while watching the production process. In addition, the price is cheaper than through an order.

The strategy used in analyzing Cikole luwak coffee product uses Product, Price, Promotion and Place variables. Product. The product is a result created by the company in this case luwak coffee developed by CV. Kopi Luwak Cikole. Luwak coffee product has a unique output compared to ordinary coffee because it goes through a fermentation process by Luwak. Luwak coffee production process is quite long and good care of the Civet animals. So that the volume of Luwak coffee production is not much because of the limited number of captive luwak. A Luwak produces 600 grams / day or around $12 \mathrm{~kg} /$ head / month.

There are two types of products marketed at CV Kopi Luwak Cikole, namely: Weasel Moon and Panda weasel The first product is the Weasel Moon is a type of luwak coffee stamina derived from coffee beans fermented by male mongoose. This product is specifically for men who want excellent stamina, but this variant is small in number. The second type of product is the original luwak coffee derived from coffee beans from female Luwak fermentation. The amount of production is quite a lot. Luwak coffee products are packaged / wrapped in two types of packaging, namely Luwak coffee stamina with a size of 100 gram for 10 sachets. While the original luwak coffee with a size of 150 / gram for 10 sachets. Price of original coffee size 150 / gram for 10 sachets Rp300,000. Price of male Luwak coffee size 250 / gram contents of 10 sachets Rp450,000, - Price of Luwak coffee in Cikole Luwak coffee shop Rp.50,000, - / glass. The price of coffee for the export market is between Rp3,000,000 / kilogram up to Rp8000,000 / kilogram

Aside from being a beverage product, luwak coffee in CV. Kopi Luwak Cikole offers other advantages as a product advantage, namely the low caffeine level of $0.5 \%$ when compared to ordinary coffee products by an average of $3 \%-4 \%$. So it is safe for consumption. In addition, it has health benefits such as preventing neurological diseases, breast cancer, skin and diabetes.

Promotion carried out to introduce civet coffee by CV. Kopi Luwak Cikole is using advertising, i.e. install Luwak coffee brand which is alongside the main road Tangkuban Perahu between the city of Bandung and the city of Subang because along the road there are many tourist destinations. In addition, using billboards and social media. Besides the promotional media above, educational tours are also carried out during the 
school holiday season, namely to introduce the mongoose animals to school children. In addition, the process of coffee maintenance, treatment and production is explained.

Distribution of product made by CV. Kopi Luwak Cikole is done directly not through resellers or other business intermediaries to guarantee the authenticity and quality of the product. As for the distribution of products abroad, there were no problems because the number of export products was limited. The reason is that to meet local market demand is still difficult because the amount of demand is greater than the amount of production.

\section{SWOT analysis}

SWOT analysis is used to identify various factors that exist in the external and internal environment which are carried out systematically to formulate the objectives of the company's strategy. This analysis explains logically how to maximize existing strengths and minimize internal weaknesses combined with external forces related to opportunities and threats that always arise. In conducting a SWOT analysis on Luwak coffee products produced by CV. Kopi Luwak Cikole as follows:

\section{Internal environment}

Strengths: Human resources control the cultivation / breeders of Luwak which are used as media for producing Luwak coffee; Farms, production processes and coffee shops become one integrated business location; Civet cultivation can be developed sustainably and production can be increased; Has product variants and attractive packaging sizes; The usefulness of the product is not only as a beverage but also offers other benefits as a food supplement Weakness: Product prices are still high and cannot be reached by the lower middle class; Low product promotion; Limited area of business development and also a vehicle parking area; In the short term the manager cannot increase / force a higher level of production; Production costs associated with maintaining and feeding are still high.

\section{External environment}

Opportunity: Market share for luwak coffee is still high because of the low availability of products in the market; The company's environment is supported by many tourism objects so it gets an easy promotional effect and becomes one of the alternative tourist destinations; Government support on developing MSMEs makes it easy for companies to obtain financial loans and trainings; At least the existing competitors make supply and marketing continue to grow
Threats: There is a movement from animal lover activists, who respond to the exploitation of mongoose as a production medium; There are still contradictions in the community regarding halal labels on Luwak coffee products; Price competition by competitors; Intensive promotion carried out by competitors

Combination of SO strategies: Utilize a sizable market share with an increase in Luwak coffee production through the development of mongoose cultivation on a larger scale. Combination WO strategy: Improving the quality of Luwak coffee products through exercises provided to employees to be more creative and innovative. Combination of ST strategies: Collaborating with suppliers in providing food intake for the mongoose; Cooperating with the health department and community organizations the importance of developing luwak culture

WT Combination: Carry out marketing activities such as participating in culinary events related to MSME products

\section{CONCLUSION AND SUGGESTION}

The large market share of Luwak coffee is still unable to be fulfilled, both foreign and domestic markets due to limited production levels. Marketing strategy developed by CV. Kopi Luwak Cikole through marketing mix. Its marketing benefits from the promotion of tourism destinations, product quality, and production stability which is maintained with breeding patterns. The SWOT analysis results show that CV. Kopi Luwak Cikole has many internal advantages and has considerable development opportunities, combined with SO strategies, namely to improve the company's sales performance internally to take advantage of the vast market opportunities at home and abroad.

Development and application of the CV marketing strategy. Kopi Luwak Cikole needs to be optimized to reach the target market through a marketing mix. Efforts are made to improve internal weakness factors such as high production costs causing high product prices. So it is not affordable for all people. Often do socialization and events to introduce their products. 


\section{REFERENSI}

[1] N. A. Hamdani, T. Susanto, and G. A. F. Maulani, "Framework of architectural marketing capabilities in regional development bank," Int. J. Eng. Technol., vol. 7, no. 3, pp. 166-169, 2018, doi: 10.14419/ijet.v7i3.25.17539.

[2] A. D. Anggraeni, "Marketing Plan sebagai Upaya Pencapaian Strategi Pemasaran Perguruan Tinggi Swasta," Bus. Innov. Entrep. J., vol. 1, no. 1, pp. 44-47, 2019, doi: 10.35899/biej.v1i1.14.

[3] Assauri,S.2017.ManajemenPemasaran,Cetakan ke-15. Jakarta: Raja Grafindo Persada

[4] Alma, B. 2009.ManajemenPemasaran, Edition Revisi. Bandung: Alfabeta.

[5] Baker, M. J. 2003. One more time-what is marketing?.2003. In The Marketing Book. Fifth Edition. Baker, M. J. (Eds). Burlington MA: Butterworth-Heinemann.

[6] Cowan, L. 2014. The Four Faces of Marketing. The Missing Link between Marketing \& Management. $1^{\text {st }}$ edition. Bookboon.com

[7] Cravens, D., W.2000. Strategic Marketing. $6^{\text {th }}$ edition. Boston: McGraw-Hill.

[8] Creswell, J.,W.2017. Research Design :Pendekatan metode Kuantitatif, Kualitatif dan Campuran. Edition ke-4. Yogyakarta : Pustaka Pelajar.

[9] David, F.,R.2002.Manajemen Strategy. Edisi Bahasa Indonesia. Jakarta: PT. Prenhallindo.

[10] Er, A.C., \& Simon, S. 2015. Marketing mix of Ecotourism Product in Kuching, Sarawak, Malaysia. Mediterranean Journal of Social Sciences, Vol.6, No.4, pp.1-9.

[11] Foxall. G.R. 2003. Consumer decision making: process, level and style. In The Marketing Book. Fifth Edition. Baker, M. J. (Eds). Burlington MA: Butterworth-Heinemann.

[12] Jain, M., K. 2013. An Analysis of Marketing Mix: \&Ps or More. Asian Journal and Multidisciplinary Studies, Vol.1, No.4, pp.1-28.

[13] Aydin. K\& Mtetwa, T. 2016. Impact of marketing effectiveness and capabilities, and export market orientation on export performance. Evidence from Turkey. European Business Review, Vol.28, Issue:5, pp.532-559.

[14] Keagan, W. 2003.ManajemenPemasaran Global. Jakarta: PT.Gramedia Pusaka Utama.

[15] Kotler, P.2000. Marketing Management. Tenth edition. United States of America: Prentice-Hall, Inc.
[16] Kotler, P. 1995,ManajemenPemasaran. (Analysis, Perencanaan, Implementasi, dan Pengendalian ). Edition ke-6. Jakarta: Erlangga.

[17] Kotler, P., \& Keller, K., L. 2009. Marketing Management. $13^{\text {th }}$ edition Upper saddle, NJ: Prentice-Hall.

[18] Kotler, P., \&Gerry A. 2003. Principle of Marketing. $9^{\text {th }}$ edition. New York: Prentice-Hall International, Inc.

[19] Malcom, M. 2003. Strategic Marketing Planning: Theory and Practice. In The Marketing Book. Fifth Edition. Baker, M. J. (Eds). Burlington MA: Butterworth-Heinemann.

[20] Purnomo, H., S. 2007.Manajemen Strategy. Jakarta: Lembaga FEUI.

[21] Rangkut. F, 2009. Analysis SWOT Teknik Pembedah Kasus Bisnis: Reorientasi Konsep, Strategi Untuk Menghadapi Abad 21. Jakarta: PT. Gramedia Pustaka Utama.

[22] Sam, K. M., Li, H.L., \& Chatwin, C. 2016. Understanding the Adoption of Online Language Learning Based on E-Marketing Mix Model. Journal of Information Technology Management, Vol. 27, No.2, pp. 65-81.

[23] Sarkar, M. A., Hossain., A, W., \& Begum, S. 2012. Investigating the Impact of Marketing Mix Elements on Tourist' Satisfaction: An Empirical Study on East Lake. Vol.4. No.7, pp. 273 - 282

[24] Stanton, W., J.1993.PrinsipPemasaran, Edisi ke7. Jakarta: Erlangga.

[25] Turnbull, P. W., \& Leek, S. 2003. Business-tobusiness marketing: organizational buying behavior, relationships and networks. In The Marketing Book. Fifth Edition. Baker, M. J. (Eds). Burlington MA: Butterworth-Heinemann.

[26] Wesley, R. 2003. The basics of marketing strategy. In The Marketing Book. Fifth Edition. Baker, M. J. (Eds). Burlington MA: ButterworthHeinemann.

[27] Sugiyono,2003,MetodPenelitianBisnis, Cetakanke-10, Bandung Alfabeta

[28] Swastha.B,2008.ManajemenPemasaran Modern. Cetakanke-13. Yogyakarta: Liberty.

[29] Tjiptono, P. 2008.PemasaraStrategi. Yogyakarta: Penerbit Andi.

[30] Supriatna,S. \& Aminah, M. 2014.AnalisisPengembanganStrategi Kopi Luwak. Jurnal Manajemen dan Organisasi, Vol V, No 3, hlm 1-18. 